\title{
Retrato: imagen del hombre y origen del arte*
}

Recibido: 22/11/2020 | Revisado: 13/07/2021 | Aceptado: 13/08/2021

DOI: 10.17230/co-herencia.18.35.13

\section{David Vázquez Couto** \\ davidcouto@usal.es}

Resumen En ocasiones la teoría del arte aborda un mismo tipo de imagen desde la disparidad discursiva. Este es el caso del retrato, cuya imprecisa definición complica su acotación conceptual y formal en los límites de la cultura occidental. Si bien este texto no pretende resolver las dudas en torno a uno de los problemas más significativos del arte -incluso el problema del arte, si es que el retrato nace con él-, sí se propone mostrar las dificultades para llegar a un acuerdo sobre las convenciones que lo definen, desde sus antecedentes en la Antigüedad y su consolidación durante la Modernidad, hasta el advenimiento de su crisis contemporánea que algunos autores atribuyen a la saturación que sufre el rostro en la sociedad de masas, y otros, al nuevo paradigma artístico que se impone a partir del impresionismo.

\section{Palabras clave:}

Arte, imagen, individuo, pintura, representación, retrato, semejanza.

\section{Portrait: Image of man and the origin of art}

\begin{abstract}
Sometimes, art theory addresses the same type of image from discursive disparity. This is the case of the portrait, whose imprecise definition complicates its conceptual and formal definition within the limits of the Western culture. Although this text does not intend to resolve doubts about one of the most significant questions in art-even the question of art, if portraits are born with it-it does attempt to show the difficulties in reaching an agreement on the conventions that define it, from its antecedents in Antiquity and its establishment in modern times, up to the advent of its contemporary crisis that some authors attribute to the saturation suffered by the image in mass society, and others, to the new artistic paradigm that is imposed from Impressionism onwards.
\end{abstract}

\section{Keywords:}

Art, image, individual, painting, representation, portrait, likeness.
* Este texto se encuadra en el proyecto de investigación Intermedialidad e institución. Relaciones interartísticas: literatura, audiovisual, artes plásticas, Ref. HAR2017-85392-P, financiado por el Ministerio de Ciencia, Innovación y Universidades del Gobierno de España, por medio de la convocatoria 2017 de proyectos I+D correspondiente al Programa Estatal de Fomento de la Investigación Científica y Técnica de Excelencia.

** Personal Investigador en Formación en el Departamento de Historia del Arte y Bellas Artes. Universidad de Salamanca, España. ORCID: 0000-0001$6971-7868$ 
Muchos teóricos sitúan la aparición del retrato en Occidente en distintos lugares y momentos de la Historia. Esto se debe a la ambigüedad natural del término que permite una relativa libertad en la interpretación de su significado, pues se trata de una idea tejida sobre una compleja red conceptual por la que se cruzan nociones como imagen, representación o mímesis, todas ellas impensables al margen del arte y de su preocupación por el hombre. En efecto, el arte debe su razón de ser al impulso del hombre a vencer a la muerte mediante la materialización de lo singular y lo distinto de cada individuo, al tiempo que este se hace consciente de su naturaleza común con el resto de la humanidad. Tal vez esta indeterminación del hombre, siempre a medio camino entre lo particular y lo general, pueda explicar, al menos en parte, por qué fracasa en su intento de verse reflejado en una imagen como realmente es.

Al ser un concepto sin un origen formal definido, tan solo sujeto a la misión de identificar al modelo para sustituirlo simbólicamente en su ausencia, el retrato ha tenido que aprovecharse de la potencialidad de cada medio que ha sometido con la intención de ofrecer la verdadera imagen del hombre, y no necesariamente logrando un parecido físico exacto. Ahora bien, como sabemos, establecer los límites de cada medio, encerrados a su vez por los límites de cada arte, es, cuanto menos, una cuestión problemática, pues determinar claramente su espacio privado y exclusivo, libre de contingencias con otras disciplinas que frecuentan los territorios fronterizos, es tan difícil -diríamos incluso que imposible- como establecer el principio y el fin del ser humano, ya sea como especie, en un sentido biológico, o como individuo, en un sentido existencial. La constitución y asentamiento de estos límites, y por tanto también de las cualidades específicas que caen en su interior haciendo ser a cada medio, nos vienen dados por los criterios institucionales de la tradición artística. Es entonces cuando el retrato se convierte en una cuestión hermenéutica que lo vincula a los orígenes del arte y a la imagen del hombre.

¿Pero qué es un retrato? No creemos que haya una respuesta completamente satisfactoria a esta pregunta, así que nuestro objetivo aquí es, por un lado, tratar de llamar la atención acerca de cómo este concepto se asume como un axioma sobre el que se erigen algunos 
discursos del arte y de la imagen, y por otro, demostrar que, a pesar de la falta de consenso teórico sobre su definición, prevalecen ciertas constantes ideológicas que perpetúan sus convenciones. A fin de cuentas, hablar de retrato es preguntarse plásticamente por el sentido del hombre y del arte, una suerte de materialidad ontológica que media entre los mundos sensible y suprasensible. Podríamos incluso aventurarnos a explicarlo como una tékhne dirigida hacia la epistémē antropológica y metafísica, pero entonces deberíamos reconocer la intención con la que el artista ejecuta la representación, tal y como lo proponen, más o menos explícitamente, autores como Francastel (1978, pp. 15-16), Todorov (2013, p. 19) o Belting (2007, p. 38). Sin embargo, esta intención, así como la fisionomía del modelo que nos permite juzgar su parecido con la imagen, es una información de la que por motivos obvios no siempre disponemos, lo que nos devuelve, una vez más, al callejón sin salida donde queda atrapado el retrato.

\section{El origen del arte: imago y retrato}

Didi-Huberman afirma que para hablar de ciertos conceptos como "imagen" o "retrato" "es imprescindible plantear la cuestión, histórica y crítica, de las relaciones que conforman su misma existencia" (2011, p. 83). Y es que, a su juicio, sobre la "relación de semejanza" se vertebra todo principio artístico, lo que nos lleva a indagar sobre las raíces del arte. Aunque admite que situar este origen en un momento concreto de la historia es simplificar en exceso la cuestión, propone al menos dos puntos de partida que "conforman un sistema" y coinciden con la publicación, primero, del libro XXXV de la Historia Naturalis de Plinio el Viejo en el año 77 d. C., y segundo, ya en el año 1550, con Le vite de' più eccellenti architetti, pittori, et scultori italiani, da Cimabue insino a' tempi nostri, de Vasari. ${ }^{1}$ Plinio introduce el mito original del arte que será recuperado e interpretado por Vasari durante el Renacimiento, y a pesar de las evidentes similitudes entre ambos textos, hay una distinción epistemológica clave que marcará el discurso artístico de la Modernidad. Mientras Plinio tiene un

En 1568 se publica la segunda edición de este tratado con el título de Le vite de' più eccellenti pittori, scultori e architettori. 
sentido abierto y general del arte, pues este se encuentra en muchas otras manifestaciones más allá de las meramente figurativas, Vasari considera el arte, o las artes (arti del disegno), como un tipo de saber elevado y concreto reservado a unos pocos privilegiados (1568, pp. 68 y 119). Vasari, por tanto, establece la distinción entre la artesanía y el arte, consolidando así una institución cuya conciencia histórica del arte llegará hasta nuestros días para valorar y determinar el objeto artístico.

Plinio nos dice que al principio fue la pintura y la plástica -o las formas con volumen del modelado con arcilla-, pues ambas forman parte del mismo proceso artístico surgido a partir del deseo de crear un doble del hombre que, antes o después, dejará este mundo para siempre:

[...] el alfarero Butades de Sición fue el primero que modeló retratos de arcilla, en Corinto, a causa de una hija suya que estaba enamorada de un joven; cuando éste se marchó al extranjero, ella trazó una línea alrededor de la sombra de su rostro proyectada en una pared por la luz de una lucerna y a partir de esa línea, su padre la modeló en arcilla y la puso al fuego para que se endureciera junto con el resto de su cerámica (Plin. HN xxxv, XII, 151).²

En este relato Plinio recurre al sentimiento nostálgico de la "añoranza" (póthos), es decir, el deseo de "lo alejado" (állothi pou óntos) y ausente, tal y como Sócrates le explica a Hermógenes en el Crátilo (420a-b) (Bailly, 2001, p. 107), para describir el proceso de la representación en dos pasos: el primero, que corresponde al ámbito de la pintura, lleva al eidôlon -"la silueta trazada por la hija sería un eidolon, o sea una imagen sin substancia, un doble impalpable, inmaterial, de aquel que se fue"-; ${ }^{3}$ y el segundo, que corresponde a la plástica, lleva al colossos -"El doble que Butades fabrica a partir de la sombra es un colossos en la acepción primitiva del término, que no

2 Para la citación de la obra de Plinio hemos utilizado la traducción realizada por M. ${ }^{\text {a }}$ Esperanza Torrego Salcedo (2001) a partir del texto de Jean-Michel Croisille publicado en 1985 por la editorial Les Belles Lettres.

3 Debray explica la evolución etimológica de "ídolo" y su relación con el "doble" a partir de su origen como eidôlon: "Ídolo viene de eidôlon, que significa fantasma de los muertos, espectro, y solo después imagen, retrato. El eidôlon arcaico designa el alma del difunto que sale del cadáver en forma de sombra intangible, su doble, cuya naturaleza tenue, pero aún corpórea, facilita la figuración plástica. La imagen es la sombra, y sombra es el nombre común del doble" (1994, p. 21). 
implica un tamaño determinado, sino la idea de una cosa erigida, de pie, durable, y animada" (Stoichita, 1999, p. 24)-. El eidôlon es aquí la matriz de la pintura, y a pesar de que Plinio admite su origen "oscuro" (incerta), "todos concuerdan que consistía en 'circunscribir con líneas el contorno de la sombra de un hombre' (omnes umbra hominis lineis circunducta)" (libro XXXV, cap. III). Como sugiere Stoichita (1999, p. 29), es probable que Plinio, a la hora de idear este relato, tuviera en mente la "pintura de sombras" (skiagraphia) que Platón menciona en la República (602d). Aquí la "magia" creadora de la ilusión mimética (goêteia) produce una imagen de lo que estuvo ahí, y en un acto de sustitución ocupa el lugar de su referente para crear una dialéctica entre la ausencia del cuerpo y la presencia de la imagen. Lo que queda en la pared es una instantánea que hace visible el rastro del cuerpo en el espacio: "[U] na imagen indexal en el sentido de la fotografía" (Belting, 2007, p. 32) que mantiene una relación simbólica con su origen. El siguiente paso del arte será encontrar un medio para que la sombra pueda materializar el eidôlon.

Didi-Huberman se da cuenta de que Plinio, cuando habla de imaginum pictura, no se refiere, como insisten los traductores de sus textos, a la "pintura de retratos". Aclara que imago es una categoría que no se corresponde con un género artístico determinado, o con la idea de obra pictórica que ha de ser exhibida como objeto artístico, sino más bien a una "suerte de género jurídico" (2011, p. 110) que reconoce a los nobles romanos el "derecho" (ius) de mantener en el atrio de sus casas las imágenes de sus antepasados. Por tanto, la "dignidad" (dignitas) del individuo se consigue mediante una "semejanza extrema" (maxima similitudo) capaz de perdurar en el tiempo para que los ancestros puedan estar presentes ante sus descendientes. Así pues, con imago, Plinio se refiere a la "máscara vaciada en cera" (expressi cera vultus) extraída a partir del rostro del difunto y destinada al culto en el entorno privado de la familia. Durante el proceso de impresión del rostro se produce un "intercambio simbólico entre muerte e imagen" (Belting, 2007, p. 38) que da como resultado lo que Didi-Huberman denomina "imagen-matriz", es decir, la imagen surgida del contacto directo 
con el modelo: "[E]1 molde realizado directamente sobre el rostro garantiza metonímicamente la presencia única e inamovible del referente de la representación" (2011, p. 126).

Antes de continuar, debemos detenernos un momento en el concepto de "representación", que según Debray encuentra una de sus primeras acepciones en la definición que ofrece Émile Littré: "En la Edad Media, figura moldeada y pintada que, en las exequias, representaba al difunto". Debray ilustra este uso de la imagen como "sustituto vivo del muerto" mediante la práctica funeraria llevada a cabo por la realeza francesa entre comienzos de los siglos XV y XVII, más concretamente entre las muertes de Carlos VI el Bienamado (1422) y la de Enrique IV (1610). En esta costumbre el difunto rey había de exhibirse ante la corte durante cuarenta días, pero con el fin de evitar la contemplación de la putrefacción y mantener la imagen incorrupta del cuerpo en la imaginación de los vivos, este era sustituido por una efigie adornada con los atributos característicos de su persona y su condición social. De este modo, mientras el cuerpo sin vida del monarca permanece oculto en algún lugar del palacio, el maniquí de cera pintada recibe las ofrendas y la veneración de la corte. Debray se da cuenta de que con este rito los franceses recuperan el funus imaginarium de la tradición romana (1994, pp. 22 23), pero si miramos más allá de los límites de Occidente podemos encontrar prácticas semejantes todavía más antiguas, como la que nos describe Heródoto en el siglo $\mathrm{v}$ a. C. hablando sobre ciertas costumbres egipcias:

Por cierto que en los festines que celebran los egipcios ricos, cuando terminan de comer, un hombre hace circular por la estancia, en un féretro, un cadáver de madera, pintado y tallado en una imitación perfecta y que, en total, mide aproximadamente uno o dos codos; y, al tiempo que lo muestra a cada uno de los comensales, dice: "Míralo y luego bebe y diviértete, pues cuando mueras serás como él” (Hdt. Hist. II, 78). ${ }^{4}$

4 También Plutarco, siglos más tarde (I-II d. C.), escribe sobre esta costumbre en Isis y Osiris (VI, 17F) y en el Banquete de los siete sabios (II, 2, 148A-B). Sin embargo, en este último texto, ya no se menciona la utilización de la efigie como sustituto del cuerpo, sino la del cadáver momificado del difunto. Aquí el propio cuerpo se ha convertido en efigie. A esta versión se refiere Montaigne cuando habla de este rito funerario en sus Ensayos (I, XX). 
Hay, pues, en estas prácticas, una usurpación de la identidad mediante la sustitución del cuerpo original por su copia. Es en este sentido que Debray afirma que los occidentales "oponemos a la descomposición de la muerte la recomposición por la imagen" (1994, p. 27). La permanencia de la imagen supera con creces la huida del cuerpo del mundo de los vivos, y por eso en el diálogo De Statuis (De Remediis utriusque Fortunae, XLI) del siglo xIv, Petrarca defiende la escultura como el método artístico más eficaz para conseguir la "eternidad material del cuerpo" (perennius corpus). Ahora bien, para Belting, "la sustitución era mucho más importante que cualquier grado de semejanza" (2007, p. 38), puesto que la intención no era tanto la de conseguir un parecido exacto, sino lograr una presencia perpetua mediante la imagen del cuerpo ausente. A esto se refiere cuando afirma que "la medialidad de las imágenes es una expresión de la experiencia del cuerpo” (Belting, 2007, p. 38). Sin embargo, precisamente la falta de semejanza es lo que preocupa a Plinio en su genealogía de la imagen. Las nuevas costumbres en el consumo del arte olvidan el culto a los antepasados para glorificar a los personajes ilustres. La semejanza se pierde justo en el momento en que importa más venerar aquello idealizado y desconocido que mantener vivo el recuerdo de un allegado ausente:

Lo cierto es que la pintura de los retratos, por la que se transmiten a la posteridad representaciones extraordinariamente fieles al original, ha caído totalmente en desuso. Se dedican escudos de bronce, efigies de plata, sin rasgos que difieren a las figuras. [...] Hasta tal punto prefieren todos que se admire el material utilizado antes que el que se les reconozca. $Y$ entre tanto, se tapizan las pinacotecas de pinturas antiguas y se admiran las efigies extranjeras, considerándolas dignas de honor sólo en la medida de su precio [...] Así, al conservarse la efigie de un individuo, no perduran sus propios rasgos, sino los de su dinero (Plin. HN xxxv, II, 4-5).

Frente a la dignidad de la semejanza, de toda similitudo naturae, estaba la "lujuria" (luxuria) de los coleccionistas que inauguran con este "sistema del exceso" lo que será la institución artística de nuestros días: una cultura del museo y un mercado que fetichiza el objeto artístico (Didi-Huberman, 2011, p. 119). Se trata de una nueva interpretación de la imagen que para Belting abre una brecha entre la "era de la imagen" de la Antigüedad, dedicada al 
culto por su carácter ritual, y el nacimiento del arte moderno, o del arte en general, si entendemos el arte como discurso ligado a una institución (2007, p. 13). Así se comprende el por qué desde el Renacimiento se desprecian las "imágenes que tuvieran un carácter artístico incierto", entre ellas, las antecesoras del retrato moderno: las máscaras funerarias y varios tipos de figuras votivas relacionadas con el culto a los muertos (Belting, 2007, p. 22). Por aquel entonces ya se daban los primeros pasos de la institución del arte que guiará el comportamiento del espectador moderno en el museo. Esto supone la "muerte de la semejanza" (Didi-Huberman, 2011, p. 121), pues la concepción pliniana del arte como imitación, e incluso como superación y transformación de la Naturaleza, hace que todo objeto artístico deba tener una semejanza con lo que representa, es decir, un anclaje referencial reconocible que evite la “crisis de la representación” (Belting, 2007, p. 23). Plinio anticipa así el fin del arte que es en realidad su origen moderno: un origen del arte que, según Didi-Huberman, ha muerto al nacer (2011, p. 108), pero que nos ha dejado en herencia un discurso desde el cual vemos sus imágenes. El nuevo gusto por el "arte" determina el significado y el valor de sus obras en función de unas preferencias estéticas que también caen bajo el dominio del discurso institucional. La "antropología de la semejanza" de Plinio (Didi-Huberman, 2011, p. 115) descubre que la historia del retrato comienza con la relación mimética que se establece entre la realidad y la imagen. El arte y el retrato son dos caras de la misma moneda.

\section{Historia y funciones del retrato}

Belting insiste, desde el particularismo histórico, en que solo se puede hablar de la historia del retrato desde una perspectiva cultural específica, que en nuestro caso comienza en los primeros años de la Modernidad (2017, pp. 2 y 5). El retrato, en cuanto "organismo estético” creado por el artista, como diría Ortega y Gasset (1965, p. 492), es también una manifestación cultural del momento de su producción que transforma el rostro en máscara de su época (Belting, 2017, p. 94). Jean M. Borgatti ya había advertido que "the mode of 
depiction may vary according to culturally held conceptions of the person, ideas about individualism, and aesthetic preferences" (1990, p. 37). Esto significa que es necesario comprender estas claves culturales para considerar como retrato la representación de alguien. El retrato solo es comprensible y pensado como tal si nuestra interpretación responde a las exigencias de la cultura en la que fue producido, es decir, como una "máscara histórica" (Belting, 2017, p. 101) que vibra entre las épocas de la tradición tratando de sincronizarse continuamente a sus manifestaciones artísticas. Arte y retrato, por tanto, comparten un mismo origen mítico, aunque no por ello menos verdadero.

El mito original del arte que nos ha dejado Plinio fue la respuesta a una incógnita que preocupaba al hombre desde hacía siglos. ¿Pero qué habría escrito si supiera que no muy lejos de donde pasó su vida esperaban pacientemente a ser descubiertas las pinturas rupestres de la cueva de Lascaux? ¿Qué interpretación habría dado de estas imágenes si hubiese sabido que fueron pintadas en el primer período del Paleolítico superior, aproximadamente 18000 años atrás? Quizá admitiría, como lo hizo Bataille (2003) al contemplar "el milagro de Lascaux", que aquí se encuentra el verdadero nacimiento del arte. Si bien es difícil imaginar que fuera tan lejos como él al pensar que no puede haber hombres antes del arte porque precisamente la capacidad del hombre para crear objetos estéticos es aquello que lo hace humano, podríamos suponer que nuestra tradición artística, y con ella también el retrato, hubiera seguido otras directrices estéticas. Nunca lo sabremos. En cualquier caso, hoy podemos acercarnos un poco más a un origen histórico del arte que, de una manera o de otra, siempre ha estado ligado al retrato, aunque solo en ocasiones a la representación de la figura humana. Rafael Argullol dice de las manos rojas de Altamira, pintadas entre 38000 y 8000 años atrás, que son "pintura y retrato simultáneamente": "El trazo simbólico, la huella, quieren convocar a la vida, al poder de existir, y conjurar a la muerte. Así debió nacer también el retrato a través de milenios: imitación, rito, proyección, trascendencia" (2009, p. 1).

Si "el arte está llamado a descubrir la verdad bajo la forma de la configuración artística”, como suponía Hegel (1989, p. 54), el retrato es la parte del arte dedicada exclusivamente a la verdad del hombre, 
al menos desde que Vasari comienza a utilizar el verbo ritrarre en este sentido, y ya no como una representación mimética de la Naturaleza (González García, 2008, p. 112). Y puesto que no hay verdad fuera del hombre y su cultura, el retrato, como el arte, es "inconmensurable" en el sentido utilizado por antropólogos, científicos y teólogos. Pero el arte, en cuanto que producto humano que hace al hombre, es siempre retrato porque el sentido de la representación no cambia. Simplemente la verdad ha cambiado de lugar y ahora está en el que antes contemplaba el mundo. Para Blanchot (1976) el arte surge en el instante extraordinario en el que el hombre, habiéndose diferenciado del resto de los animales mediante la cultura, toma conciencia de esta distancia para volver a su origen perdido en la inmensidad temporal. El arte, que jamás se desprende de un origen desconocido e inalcanzable, encuentra su verdad encubierta en este vacío. Y el "tiempo de la diferencia" al que se refiere como instante de revelación (Blanchot, 1976, pp. 13-17) es en realidad un tiempo que desaparece desplegándose en su infinitud. Es el no-tiempo de la eternidad que aparece tras la muerte, el mismo que el retrato, en su estatismo, pretende encerrar, pues en lo inmóvil no hay tiempo posible: "Fuera del tiempo, el retrato no retiene más que el tiempo, el espíritu del tiempo que se palpa en el rostro" (Bailly, 2001, p. 160).

Al menos eso parece cuando los hombres del Neolítico cubrían con yeso los cráneos en Jericó para intentar conservar los rasgos físicos de los muertos (imagen 1). Si la muerte castiga con el anonimato del cráneo y reduce al hombre al genérico de la humanidad, el impulso del vivo es rescatar la individualidad material del rostro que una vez conoció para mantener su presencia en este mundo. Aunque Francastel (1978) considera esos cráneos como "retratos indiscutibles", afirma que no surge una tendencia clara hacia el retrato hasta el tercer milenio a. n. e. en Egipto, durante el Imperio Antiguo (2700-2300 a. C.). Con todo, será tras la reunificación del Estado que supuso la instauración del Imperio Medio (2150-1780 a. C.) cuando comienzan a utilizarse las nuevas técnicas -se sustituyen los bajorrelieves por la pintura directa- que más adelante, a comienzos del Imperio Nuevo (1580-1080 a. C.), posibilitaron una mayor libertad frente a la tradición. Así pues, gradualmente se abre paso el "retrato 
de género" porque se introduce lo cotidiano en la representación mediante la asimilación de los rasgos fisionómicos del individuo (Francastel, 1978, pp. 19-27). Si en las tumbas del Imperio Antiguo aparecen las primeras pinturas de figuras antropomórficas formando parte de escenas de género que las someten a una representación tipológica, y en el Imperio Medio se simboliza la individualidad de estas figuras mediante algún rasgo distintivo que lo identifique, en el Imperio Nuevo "se agudiza la atención al individuo" (Todorov, 2006, pp. 16-17). Aparece entonces un arte funerario que se centra en los acontecimientos terrenales del difunto para rememorar su vida pasada. Se trata de pinturas naturalistas que se distinguen de la imagen que preside la tumba, cuyos rasgos idealizados permitían al muerto salirse del tiempo y viajar hasta el misterioso mundo de Osiris. Paradójicamente, esta imagen destinada a la contemplación divina -el "retrato oficial"- no conserva la personalidad como lo hacen las que decoran las paredes del sepulcro con un estilo liberado de exigencias trascendentales (Francastel, 1978, p. 27). Por eso Todorov sitúa el primer retrato conocido en el Egipto del Imperio Nuevo, concretamente en uno de los muros pintados al fresco del palacio de Tell al-Amarna, donde se representa a dos de las hijas de Akenatón y Nefertiti: Neferure y Neferneferure (imagen 2). Esta imagen no solo se diferencia del ideograma de las épocas pasadas, sino que por primera vez se produce "la irrupción de lo cotidiano en la vida regia". Esto implica un cambio de función en la imagen, que ya no está dirigida a los dioses, sino a las personas que conocen o han conocido al individuo representado: "Una imagen no destinada a que la vean ojos humanos no es un retrato" (Todorov, 2006, pp. 17-18). 


\section{Imagen 1}

Cráneo de Jericó, hacia 8200-7500 a. C.

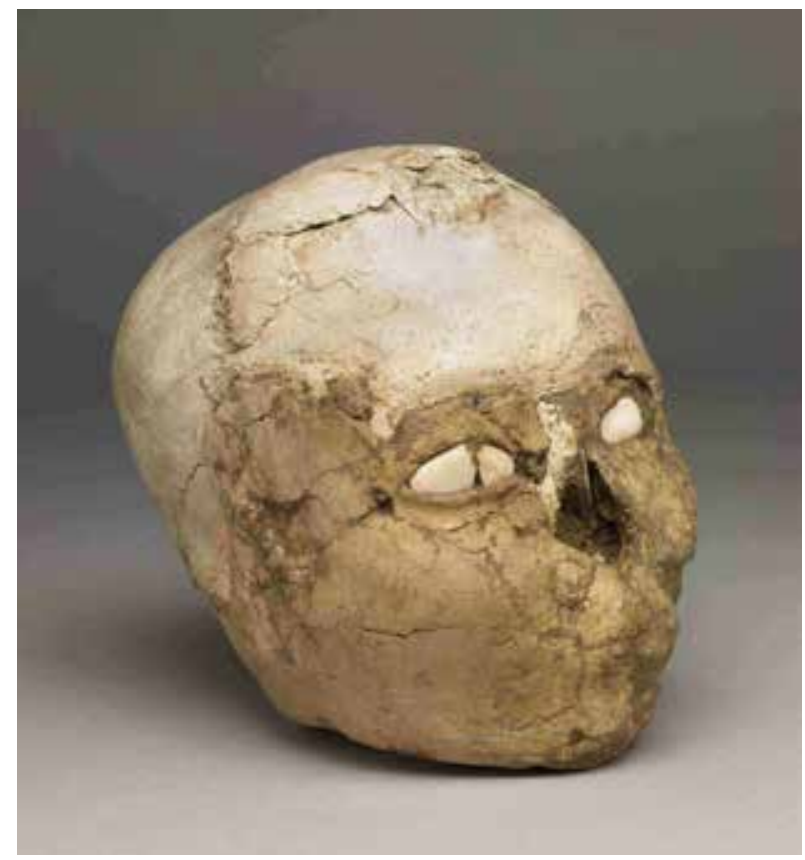

The British Museum, Londres.

\section{Imagen 2}

Neferure y Neferneferure,

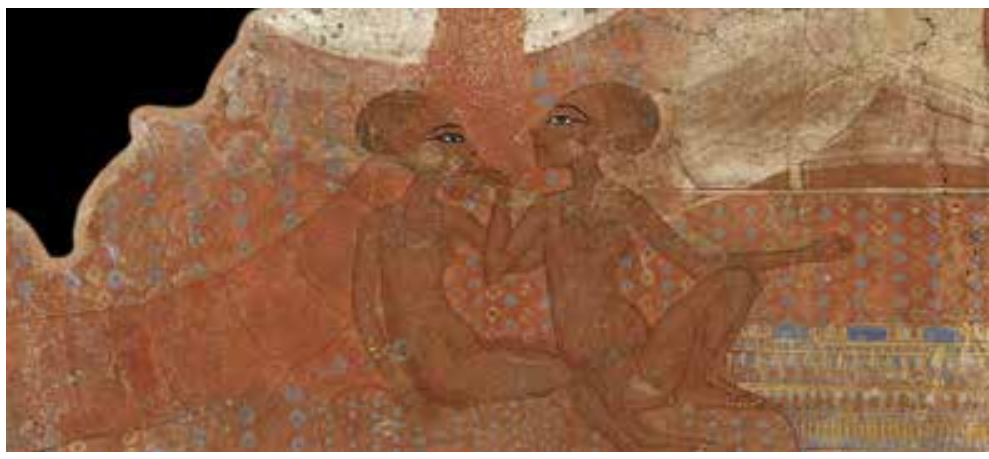

Palacio de Tell al-Amarna (Egipto), siglo XIV a. C. Pintura al fresco, 40 x $165 \mathrm{~cm}$, Ashmolean Museum, University of Oxford. 
También de esta época data el "retrato personal" de la reina Ahmes, cuyos "rasgos fugitivos captados en una síntesis incisiva" (Francastel, 1978, pp. 28-29) permiten reconocerla en las distintas imágenes que conservamos de ella. La progresiva individualización se hace evidente si comparamos estas imágenes con la representación esquemática del rey Narmer (I dinastía del Imperio Antiguo) en la paleta de esquisto fechada alrededor del año 2950 a. C. Aquí el rey no se diferencia de las demás figuras más que por la corona que ostenta sobre la cabeza y porque han escrito su nombre en la piedra. "Se roza así el retrato, pero no se alcanza" (Francastel, 1978, p. 13), ya que la figura es todavía un signo que necesita parecerse algo más a su referente para adquirir tal categoría. En cambio, para Borgatti (1990) esta falta de semejanza no impide considerar las imágenes como retratos, siempre y cuando sea posible documentar las identidades a las que hacen referencia, aunque, como sucede con algunas de las máscaras conmemorativas de los Okpella de Nigeria, ni siquiera sean antropomórficas (1990, p. 37).

De hecho, el retrato es un concepto compartido por todas las culturas del mundo, solo que su manifestación varía en función de los conceptos que cada cultura tenga sobre el individuo y la estética en un momento concreto de la historia (Borgatti, 2008, pp. 303-304). Así se explica cómo, a diferencia de la cultura europea moderna y al igual que las culturas de la Antigüedad, los retratos africanos "emphasize social identity rather than personal identity and evidence an aesthetic preference for the general and ideal rather than the idiosyncratic and representational" (Borgatti, 1990, p. 37). Mientras el arte occidental se interesa por la identidad individual mediante la representación basada en la semejanza fisonómica, en África predomina una estética generalizadora derivada de una inclinación hacia la función social del individuo como estrategia para su identificación (Borgatti, 2008, p. 306). También Winter se refiere a las imágenes de la realeza mesopotámica como retratos porque en ellas tiene lugar "the three-way relationship between image, identifiable referent, and meaning" (2009, p. 270). Siguiendo la idea propuesta por Henri Zerner (1993) en "L'effet de resemblance", Winter sostiene que la perfecta semejanza no es una condición indispensable del retrato, puesto que se trata de que el espectador realice un acto de reconocimiento, y no tanto de que 
el artista realice un acto de semejanza. Esto revela la intención de identificar al modelo mediante los elementos y las cualidades ideales que hacen referencia a su lugar en la sociedad: "II]s a semiotic, rather than a mimetic, representation" (Winter, 2009, p. 269). Esto demuestra cómo el retrato está condicionado por el sistema cultural al que pertenece, pues se considera en la misma medida que se considera al individuo. En este sentido, podría decirse que la imagen de un hombre se convierte en retrato cuando se amolda a los códigos culturales que mitifican la identidad dentro de una sociedad.

La gran discrepancia entre Francastel y Todorov surge de sus opiniones respecto al retrato en Grecia. Francastel desecha totalmente el retrato griego debido a la subordinación de su arte a un canon de belleza ideal que impide la representación de las particularidades del individuo. Es más, asegura que "el retrato renace y evoluciona únicamente manteniéndose alejado del gran centro de la cultura griega" (1978, p. 36). Esta es una afirmación problemática, ya que al excluir el componente ideal de la imagen para centrarse casi exclusivamente en la semejanza, se niega la influencia de la cultura clásica en el retrato moderno. Y, sin embargo, como veremos más adelante, Francastel defiende el retrato como un producto del refinamiento cultural (1978, p. 53). Todorov, en cambio, considera que Grecia es "la auténtica patria del retrato europeo" porque adopta dos tipos de funcionalidad, a pesar de que no se conservan ejemplos materiales que lo demuestren. La primera, que corresponde al arte funerario, deja de ser mágica como en el arte egipcio para empezar a ser "conmemorativa". Ahora los destinatarios son seres humanos que han conocido al difunto, por lo que es preciso lograr una fidelidad de los rasgos fisionómicos que permitan el reconocimiento. La segunda es una función "glorificadora" heredada de los bustos públicos de los faraones aparecidos en el siglo IV antes de nuestra era. Este tipo de retrato goza de una mayor autonomía para idealizar al modelo debido a que está dirigido a aquellos que no han visto nunca al difunto. Ya no es necesario que guarde un grado de semejanza que

Belting hace una distinción parecida entre "la imagen conmemorativa, que tiende al realismo, e imagen heroizada, que requiere cierto grado de idealismo" (2009, p. 135). 
permita conocer sus rasgos fuera del ámbito privado, sino que sea "verosímil" para poder reconocerlo (Todorov, 2006, pp. 20-22).

Durante el Imperio romano aparecen, debido a su creciente accesibilidad y expansión popular, dos nuevas funciones del retrato que continúan el caminoabierto por losgriegos: la "estética" o "contemplativa" y la "amorosa". La primera de estas funciones se refiere al uso privado de los bustos de celebridades como Homero o Sócrates, que, como ya había denunciado Plinio en su Historia Natural, han pasado de exhibirse en los espacios públicos a decorar los interiores de las casas de los ciudadanos romanos, incluso ignorando los verdaderos rasgos de estos personajes, pues "se materializan, de acuerdo con los deseos, rostros de los cuales la tradición no nos informa” (HN xxxV, II, 9). La segunda aparece en los retratos encargados por los modelos a pintores de oficio, "al parecer sin otro objetivo que el placer de ver su imagen representada", como el caso de Terencio Neo y su esposa, panaderos de Pompeya pintados entre los años 40 y 75 d. C. (imagen 3).

Imagen 3

Retrato de Paquio Próculo

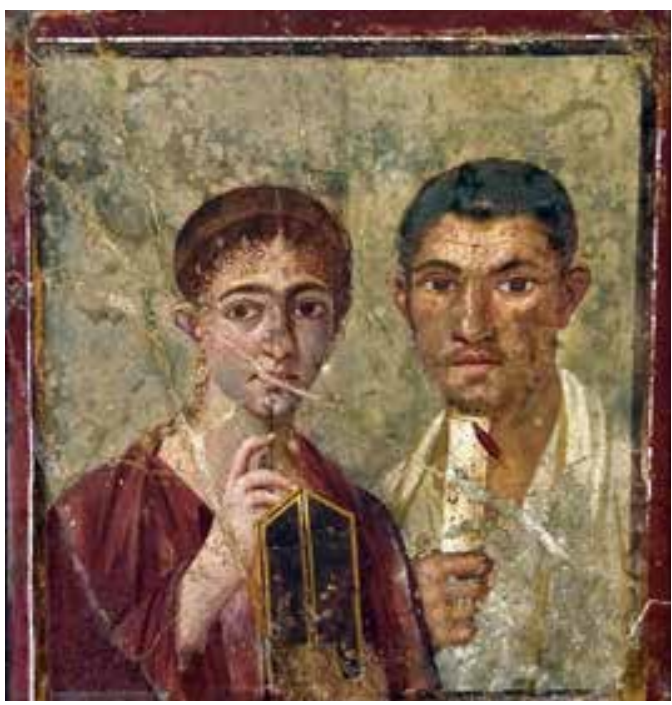

(Terentius Neo y su esposa), Pompeya (Italia), hacia 40-75 d. C. Pintura al fresco, 65 x 58 cm, Museo Archeologico Nazionale, Nápoles. 
Para Todorov este es el primer retrato europeo que se conserva, ya que debe su existencia a la misma voluntad que creó los retratos del amado de la hija de Butades de Sición y de Neferure y Neferneferure (2006, p. 26). Además, tampoco se puede pasar por alto que este retrato, al igual que otros del IV estilo pompeyano como el Retrato de la llamada Safo (55-79 d. C.), tiene la "moderna" particularidad de dirigir su mirada al frente para entablar un contacto directo con el espectador, algo que la ocupación romana de Egipto llevó hasta los sarcófagos de los inmigrantes asentados en la zona durante el período helenístico (323-30 a. C.). Como resultado del encuentro entre las culturas greco-romana y egipcia surge entre los siglos I y III de nuestra era un corpus de casi mil rostros pintados sobre tabla que cumplían una doble función: "[...] eran retratos de identificación [...] para el viaje de los muertos" y "durante un breve periodo, servían de recordatorios de los fallecidos para la familia" (Berger, 1998, párr. 8). ${ }^{6}$ Esta segunda función, "conmemorativa" y "amorosa" si utilizamos los términos de Todorov, aleja al fallecido del espectador divino, principalmente porque se piensa al hombre en su condición efímera y mundana. Apoyándose en las diferencias genealógicas en torno al arte funerario de griegos y egipcios que Erwin Panofsky expone en Studies in Iconology (1939), Bailly insiste en que ambos comportamientos ante la muerte están implícitos en los retratos de El Fayum.

\footnotetext{
Aunque no cita la fuente bibliográfica, Bailly señala que fue el egiptólogo Sir William Petrie el primero en sugerir un uso no funerario de estas imágenes (2001, p. 113).
} 


\section{Imagen 4}

Retrato de una mujer, Hawara, El Fayum (Egipto)

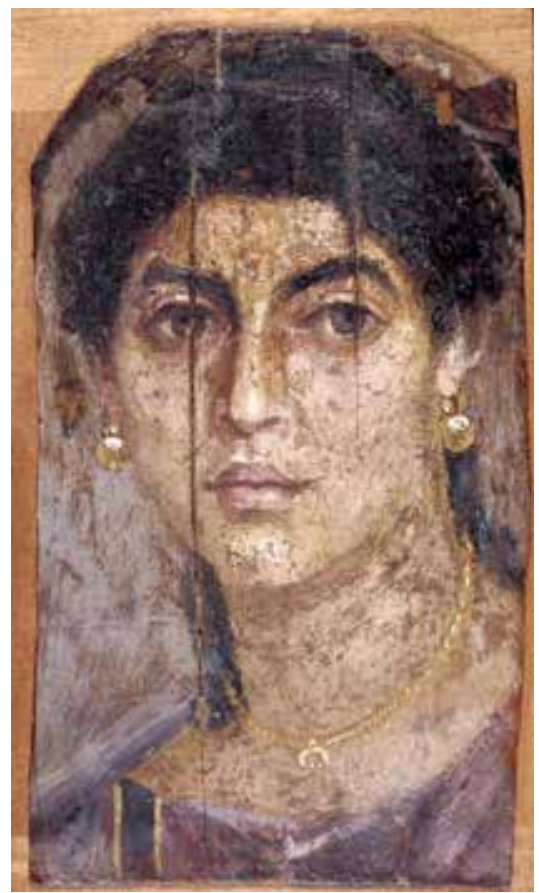

Hacia 55-70 d. C. Encáustica sobre madera de tilo, 35,80 x 20,20 cm, The British Museum, Londres.

La continuidad de la existencia de los egipcios y el abrupto final de la vida de los griegos se encuentran tras la muerte sobre una misma imagen que incorpora a la momia "el signo de la rememoración" mediante la semejanza (Bailly, 2001, p. 109). A Bailly no le cabe la menor duda de que estas imágenes son los primeros retratos conocidos en un sentido moderno, no solo debido a su humanismo tácito, sino también porque están realizados "de busto y de frente" (2001, pp. 10 y 17). La forma y la frontalidad de la mirada nos hacen ver la muerte en aquellos rostros que nos miran desde el más allá. Pero miran sin ver, porque, como actores deslumbrados por los focos del escenario, ante ellos desaparece el patio de butacas y el público para el que habían estado actuando durante sus cortas vidas. Desde 
hace casi dos milenios contemplan un vacío eterno que ahora vemos reflejado en el profundo abismo de sus miradas desaparecidas. Si Bailly habla del retrato como la exposición del "ser-para-la-muerte" (2001, pp. 16 y 71), es porque en estos rostros se intuye la muerte que a todos lleva en soledad. Y es que morir es el acontecimiento más individual de la vida, a pesar de no haber nada más común entre los hombres.

A la tradición artística europea le costará unos quince siglos volver a admitir semejante osadía de la mirada.? Debido a la nueva relación entre el hombre y la imagen que comienza a forjarse durante el siglo III d. C. bajo la sombra de la teoría neoplatónica impulsada por Plotino, se aspira a representar la Idea más que imitar las formas visibles. Porfirio nos hace llegar una anécdota sobre Plotino que ilustra este desprecio por las apariencias. Cuando uno de sus discípulos más aventajados, Amelio, le pide que pose para un retrato, el maestro responde: "¿Es que no basta con sobrellevar la imagen con que la naturaleza nos tiene envueltos, sino que pretendes que encima yo mismo acceda a legar una más duradera imagen de una imagen, como si fuera una obra digna de contemplación?" (Porfirio, Plot., 7-10). Esta connotación despectiva que adquiere el cuerpo frente al alma se convierte en repulsa por la existencia terrenal y sus representaciones. Paulino, obispo de Nola del siglo v, popularizó aquello de que "el 'hombre celestial' (homo coelestis) no puede ser representado, el 'hombre terrenal' (homo terrestris) no debe serlo" (Belting, 2009, p. 128; Todorov, 2006, p. 36). Ahora bien, este pensamiento iconoclasta que ya podíamos encontrar en las tradiciones judía e islámica (Le Breton, 2013, p. 32), admite excepciones si es para educar al pueblo en el dogma cristiano. Se permiten, por tanto, las imágenes que se ponen al servicio del discurso religioso, mientras que se condenan las destinadas a la vana contemplación. Así pues, el retrato de la tradición cristiana nacida en el seno del Imperio romano seguirá los cauces de las imágenes conmemorativas de los retratos funerarios de la Antigüedad hasta convertirse en "iconos" (eiköne). Este tipo

\footnotetext{
Mientras tanto, los retratos de El Fayum permanecerán ocultos para Occidente hasta que en 1615 Pietro della Valle traslada uno de ellos a Europa desde Saqqara, la principal necrópolis de Memphis. La erupción del Vesubio mantuvo en secreto el retrato de Safo hasta 1760 y el de Terencio Neo y su esposa hasta 1868.
} 
de imagen pintada sobre tabla y destinada al uso ritual, ya sea con la conmemoración de carácter privado en el sepulcro o con el culto oficial y público en el templo, se convierte en retrato durante la Modernidad temprana (Belting, 2017, p. 118) al volver su mirada hacia el mundo profano y cotidiano del individuo que ya habíamos visto en algunas paredes de los templos egipcios.

Durante el siglo IV, cuando el Imperio romano comienza a desmoronarse, se produce el gran desarrollo del retrato en sus diferentes propuestas técnicas que lo vinculan a la concepción moderna del término. Si bien es cierto que el cambio de preferencia por la técnica pictórica -en detrimento de la escultórica- facilita la "tarea de investigación sobre la naturaleza del ser humano, que desde ese momento será la función dominante del retrato" (Francastel, 1978, pp. 49-50), no se puede negar que esto hubiese sido imposible bajo la sombra del fundamentalismo religioso. Francastel se deja llevar por las ideas evolucionistas de Lewis H. Morgan cuando apunta a los bárbaros como los culpables de un retroceso cultural sufrido por Occidente tras las invasiones del territorio romano. Así pues, según Francastel, la libertad del individuo se vio gravemente degradada por la imposición de una cultura "arcaica", afirmando que el retrato "es un hecho propio de las civilizaciones evolucionadas porque es el resultado de una meditación elevada" (1978, p. 53). Dejando de lado la problemática del universalismo como perspectiva teórica, no hay que olvidar que mientras los bárbaros cruzaban los limes romanos en el año 380 d. C., el emperador Teodosio I el Grande declaraba el cristianismo niceno religión oficial del Imperio con el Cunctos Populos, más conocido como el Edicto de Tesalónica. Esto sería el principio de la decadencia del retrato antes de que en el año 391 d. C. proscriba los cultos paganos y sus imágenes (Todorov, 2006, p. 41). El trivial naturalismo de las escenas paganas fue sofocado por la ortodoxia en favor de un arte dedicado a las grandezas de los jerarcas del Estado. Se interrumpe así una etapa milenaria de continua exploración artística y humana, y el retrato, así como el individuo al que representa, se adentran durante siglos en las tinieblas de la oscuridad medieval. 
Pero ciertos privilegios nunca dejarán de estar al alcance de unos cuantos, y en Roma, ahora convertida en residencia del papa, el retrato se resiste a sucumbir a la condena ideológica porque los pontífices reclaman su derecho a ser retratados del mismo modo que los soberanos. Desde el siglo v y hasta finales del IX, el retrato papal, a pesar de sufrir modas que crearon ciertas convenciones tipológicas, se ha preocupado por la identificación de sus modelos (Francastel, 1978, p. 64). Son, por tanto, el papado y la realeza quienes mantienen vivo el retrato en Occidente hasta que se consolida la figura del "donante" entre finales de los siglos IX y XI. A partir de este momento es posible adquirir el derecho a ser representado consiguiendo el favor y la protección divina gracias a la donación, pues "era la forma de licitar la imagen personal mediante el ofrecimiento de un objeto de santidad" (1978, p. 68). De este modo, poco a poco el individuo va ganando terreno en la representación de la escena religiosa hasta llegar a verlo junto a La Virgen de Autun (Jan van Eyck, 1435), compartiendo la misma posición privilegiada en el espacio (imagen 5). Se produce así un "acercamiento de lo sagrado a lo profano" (Todorov, 2006, p. 120) con el que el hombre pretende contemplar el rostro de Dios mirándolo directamente a los ojos, quizá para preguntarle acerca de su creación y de su lugar en el mundo. 


\section{Imagen 5}

Jan van Eyck, La Virgen del Canciller Rolin (ca 1435)

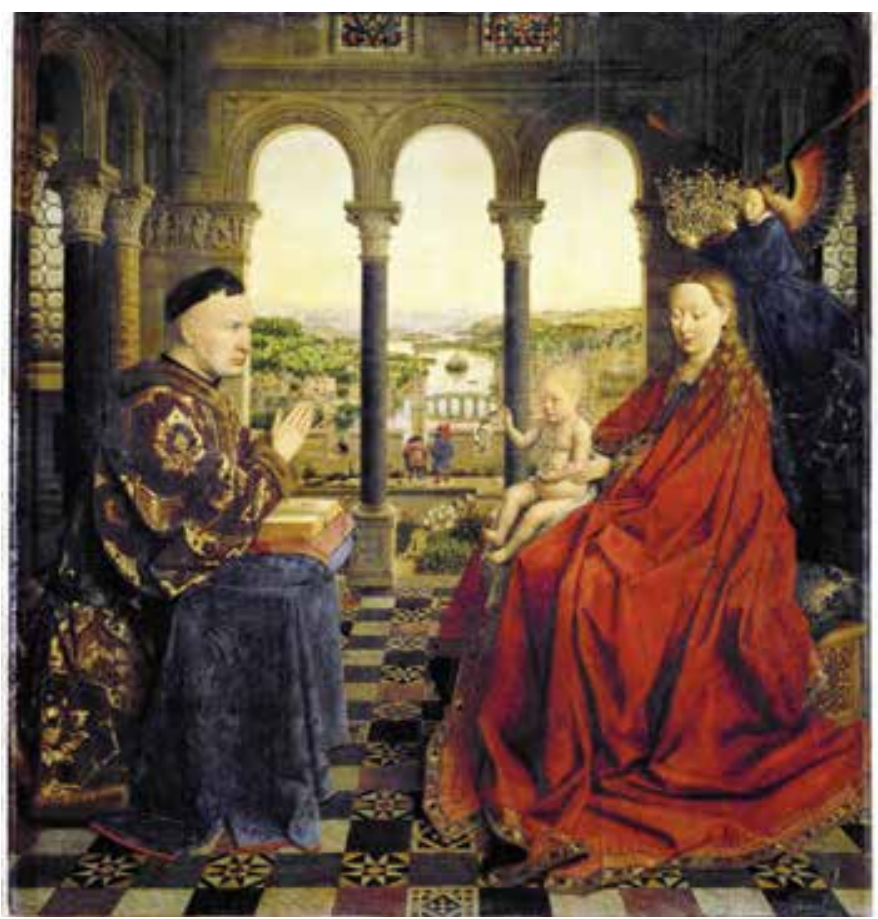

Óleo sobre tabla, 66 x 62 cm, Musée du Louvre, París.

En los manuscritos iluminados encargados por la Iglesia, sobre todo en la Alemania de la dinastía sajona u otoniana, se produce otra intromisión del individuo en la representación. En ocasiones, como en el caso del salterio de Eadwine, ${ }^{8}$ estos textos introducen la imagen del escriba en un cuadro independiente (imagen 5). Este simple hecho formal de separar la imagen del conjunto y convertirla en una pieza autónoma supone un afán de reconocimiento e individualidad

8 Eadwine fue un monje de Canterbury que después de traducir e ilustrar una copia inglesa del salterio de Utrecht en el siglo XII obtuvo el derecho a incorporar su propia imagen en una de las hojas del manuscrito. Rodeando la figura del escriba se puede leer: "Scriptor: Scriptorvm princeps ego $\cdot$ nec obitura deinceps lavs mea nec fama $\cdot$ qvis sim mea littera clama - Littera: Te tua scriptvra qvem signat picta figura . Predicat Eadwinvm fama per secula vivum - ingenium cvivs libri decus indicat hvivs . quem tibi seque datum mvnvs Deus accipe gratvm". 
que supone un gran avance hacia la conquista del "retrato libre", en el doble sentido que le otorga Francastel: "[...] objeto amovible y del derecho del individuo a presentarse sin otro objetivo que el de mostrarse" (1978, p. 74). Esta "sed de celebridad" es un fenómeno nuevo que implica una voluntad de salir del anonimato, tanto del modelo como del artista (p. 70), cuyas miradas se unen sobre un medio que alguna vez se hará presente ante el espectador. Mientras el espectador contempla, el modelo y el artista aparecen.

\section{Imagen 6}

Tripartitum Psalterium Eadwini (ca 1320)

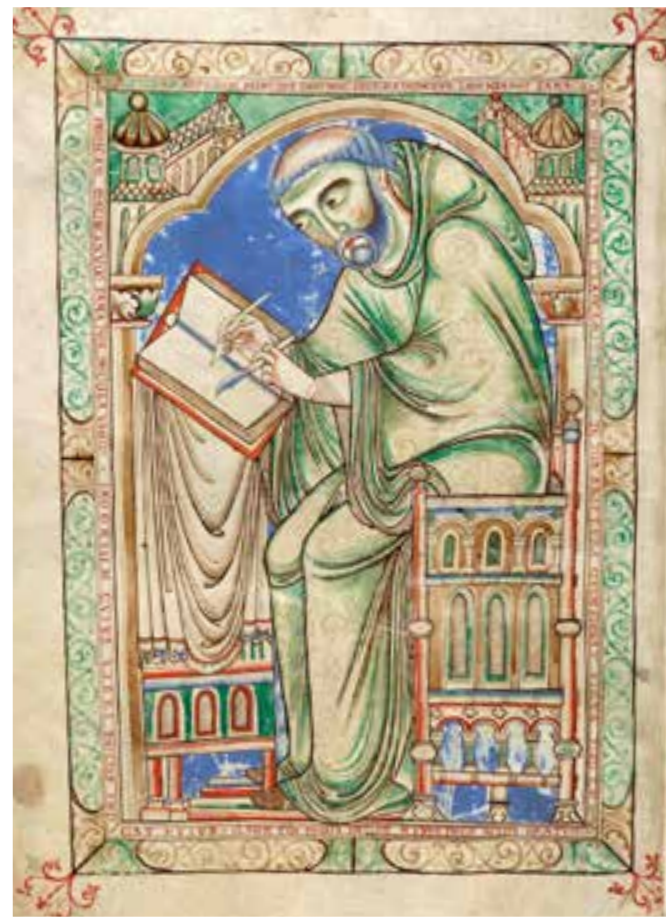

Pintura sobre papel, $46 \times 33 \mathrm{~cm}$, Trinity College, Cambridge.

El primer retrato "libre" (Francastel, 1978, p. 86) o "independiente" (Todorov, 2006, p. 102) que se conserva en Occidente es un panel de madera pintado hacia 1349 de Juan II de Francia, un rey que no se 
presenta como tal en su imagen -si bien es cierto que en ese momento todavía no era rey-, sino como un hombre más cerca de la tierra que del cielo, cuyo rostro se distingue de cualquier otro (imagen 7). Esta imagen supone la intuición material de lo que estaba por llegar con los retratos de perfil en el Renacimiento italiano, como el Retrato de Giovanna degli Albizzi Tornabuoni (1489-1490), de Ghirlandaio, que añade a la imagen un epigrama de Marcial (x, 32, vv. 5-6) para resumir la ideología renacentista sobre el retrato: "Ars, utinam mores animumque effingere posses. Pulchrior in terris nulla tabella fuerit". El arte, una vez más, mira en la misma dirección que el retrato, pues ambos se alían con un objetivo en común: "[E]l hombre y su espíritu", como escribió da Vinci (1995, p. 78). Los primeros retratos del Renacimiento son obras de "culto a la personalidad" porque a partir de este momento el artista es "un intérprete cuyo hábito es explorar la mente” (Pope-Hennessy, 1985, p. 10). Sacar a la luz lo que está oculto en el cuerpo es la preocupación del pintor durante estos comienzos de la Modernidad.

9 Tanto es así que, durante el siglo xvi y en base al tópico del vultus vivens, se llega a "la acepción de retratar como 'hurtar', en el sentido de 'robar la propia imagen”' (González García, 2008, p. 104). La literatura romántica del siglo XIX rescata esta idea con The Oval Portrait (1842), de Edgar Allan Poe, donde el artista le quita la vida a su amada modelo a medida que pinta su retrato. Algo más tarde, Oscar Wilde reinterpreta el tema con The picture of Dorian Gray (1890). 


\section{Imagen 7}

Juan II de Francia (Juan el Bueno) (ca. 1350)

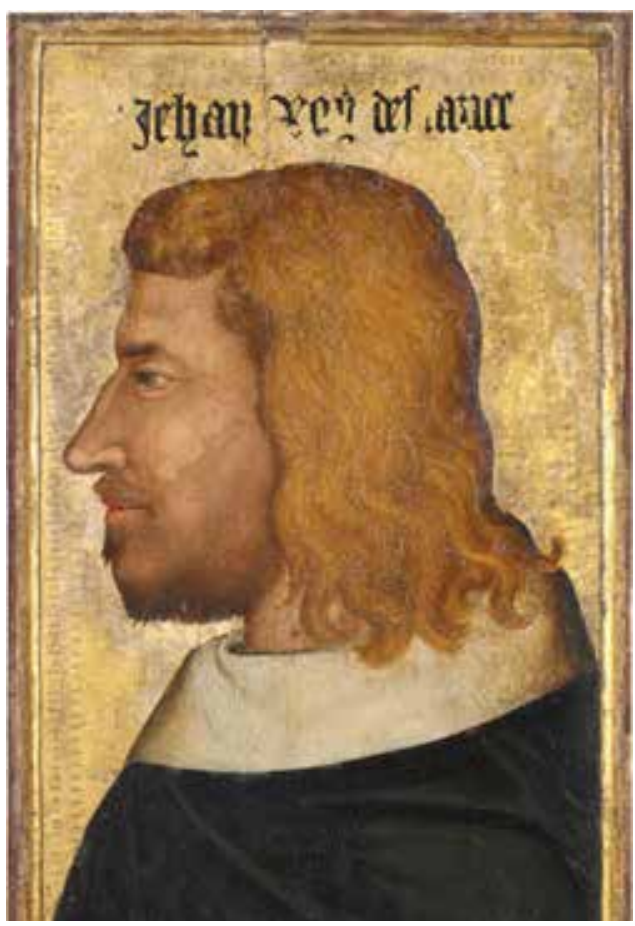

Óleo sobre tabla, 60 x 45 cm, Musée du Louvre, París.

Desde el diálogo De tristitia et miseria en De remediis utriusque fortunae (1366) de Petrarca, hasta el Oratio de hominis dignitate (1486) de Pico della Mirandola, pasando por las obras de Bartolomeo Fazio (De excellentia et praestantia hominis, 1446) o de Gianozzo Manetti (De dignitate et excellentia hominis, 1452), entre otros, se defiende la "dignidad humana" (dignitas hominis) frente al desprecio por una existencia terrenal llena de pecado y sufrimiento que dominaba el pensamiento medieval. Ahora el hombre tiene en su mano la posibilidad de "realzarse" (regenerari) o "degenerarse" (degenerare) acercándose o alejándose de Dios. El hombre es, como 
dice Della Mirandola, plastes et fictor de sí mismo, ${ }^{10}$ y el retrato es el reconocimiento de su (virtus). Con este pensamiento surgido de la teología de la imagen que piensa al hombre como (imago Dei) comienza la perspectiva antropocéntrica moderna que sustituye al teocentrismo medieval. En este momento la retórica, en especial el encomium del género epidíctico, cuyo propósito era ensalzar las virtudes morales del retratado, se convirtió en una forma de discurso fundamental para los humanistas del Renacimiento (González García, 2008, p. 99). Esta forma de descriptio personae tiene dos vertientes que se distinguen en la Rhetorica ad Herennium (siglo I a. C.): por un lado, effictio o kharakterismos, que "consiste en expresar y representar con palabras el aspecto físico de una persona, con los rasgos precisos para que se le reconozca" (corporis cuiuspiam forma), y por otro, nonatio o ethopeia, que "consiste en describir la naturaleza de una persona con unos rasgos determinados que, como marcas distintivas, son propias de su naturaleza" (alicuius naturae descriptio) (IV, 50). Mientras uno pretende una mímesis del aspecto externo del individuo para su reconocimiento inmediato, el otro alude a una extracción de ciertas particularidades que lo definen internamente como hombre. Según González García (2008, p. 99), los retratos pictóricos del Renacimiento nunca exceden estas formas de retrato retórico. Y en cierto sentido, la retórica jamás abandonará completamente nuestra forma de entender el retrato, pues el hombre es un animal moral sujeto a su segunda naturaleza. Las primeras definiciones del retrato aparecidas en los diccionarios enciclopédicos del siglo XVII demuestran que esta idea se hizo fuerte en los siguientes siglos. En el primer gran diccionario español, el Tesoro de la lengua castellana o española, publicado en 1611, Sebastián de Covarrubias define el retrato como "la figura contrahecha de alguna persona principal [...], cuya efigie y semejanza, es justo quede por memoria a los siglos venideros" (1611, R11).

En la segunda edición de las Vidas, publicada en 1568, Vasari amplía de forma considerable el contenido del texto original con

10 El "supremo Artesano" le dice al hombre: "Ni celeste, ni terrestre te hicimos, ni mortal, ni inmortal, para que tú mismo, como modelador y escultor de ti mismo, más a tu gusto y honra, te forjes la forma que prefieras" (Della Mirandola, 1984, §2, p. 105). 
datos biográficos y teóricos. Si nos detenemos en el capítulo dedicado al pintor florentino Domenico Puligo, ahora podemos encontrar una breve clasificación del retrato según el grado de semejanza, tanto física como "espiritual", respecto al hombre representado. Para Vasari el retrato debe ser una perfecta unión entre semejanza y belleza, pues ni la completa idealización ni el parecido exacto hacen reconocible al modelo:

[M]olti eccellenti maestri hanno fatto pitture, e ritratti di tutta perfezzione in quanto all'arte, ma non somigliano, ne poco, ne assai colui, per cui sono stati fatti. E per dire il vero chi fa ritratti dee ingegnarsi, senza guardare à quello, che si richiede in una perfetta figura, fare che somiglino colui per cui si fanno. Ma quando somigliano, e sono anco belli allora si possono dir'opere singolari, $\mathcal{E}$ gl'artefici loro eccellentissimi (1568, p. 104).

A este planteamiento estético y moral descrito por Vasari se unen las condiciones formales del retrato que comienzan a asentarse por aquel entonces. El concepto va tomando forma y se asientan las convenciones sobre el retrato que dominarán el arte occidental durante los próximos siglos. Belting habla del "retrato autónomo" en el mismo sentido que Francastel se refiere al "retrato libre" y Todorov al "retrato independiente", pues este "se convierte en su propio tema y aparece en un medio, en este caso transportable, del que recibe su carácter formalmente y en lo que respecta a su contenido" (Belting, 2007, p. 142). En otras palabras, la forma del retrato demuestra la intención del artista. De este modo, la representación del busto en tres cuartos se asocia a lo que Leonardo da Vinci describe en su Cuaderno de notas como "los mecanismos del pensamiento" (Pope-Hennessy, 1985, p. 117). ${ }^{11}$ Se trata de una nueva pintura cuya intención es descubrir la identidad del individuo mediante la propuesta formal de pintar la cabeza del modelo en tres cuartos y sin dejar demasiado espacio sobrante, de tal manera que se deja fuera de la representación todo elemento que desvíe la atención de la mirada sobre el rostro. Con el paso del retrato de perfil al de tres

11 Pope-Hennessy considera a Leonardo da Vinci el creador del retrato psicológico en tres cuartos. Todorov, en cambio, sin tener en cuenta la frontalidad de la mirada, atribuye este mérito a Robert Campin: "Es el pionero de la nueva pintura" que Jan van Eyck "llevará a su más elevada perfección” (Todorov, 2006, p. 137). 
cuartos a finales del siglo XV se busca un método pictórico para el conocimiento del hombre; un conocer a través de la imagen que se enmarca dentro la tradición humanista. Pero todavía queda un último paso en este lento proceso por el cual el modelo gira su cabeza, no sin esfuerzo, para buscar al espectador con su mirada. Se introduce así, de nuevo y tras 1500 años de espera, "la metáfora de la ventana" que nos lleva al fondo de los ojos del orfebre Leeuw (Belting, 2007, p. 156) (imagen 8) como lo habían hecho los retratos de Pompeya o El Fayum. El rostro vuelve a ser el signo de la identidad perdida que el retrato permite explorar mediante la representación. Ahora bien, el problema es cómo representamos y, por tanto, cómo conocemos. De ahí que el Renacimiento sea completamente distinto en Italia y en los Países Bajos.

\section{Imagen 8}

Jan van Eyck, Retrato de Jan van Leeuw (ca. 1436)

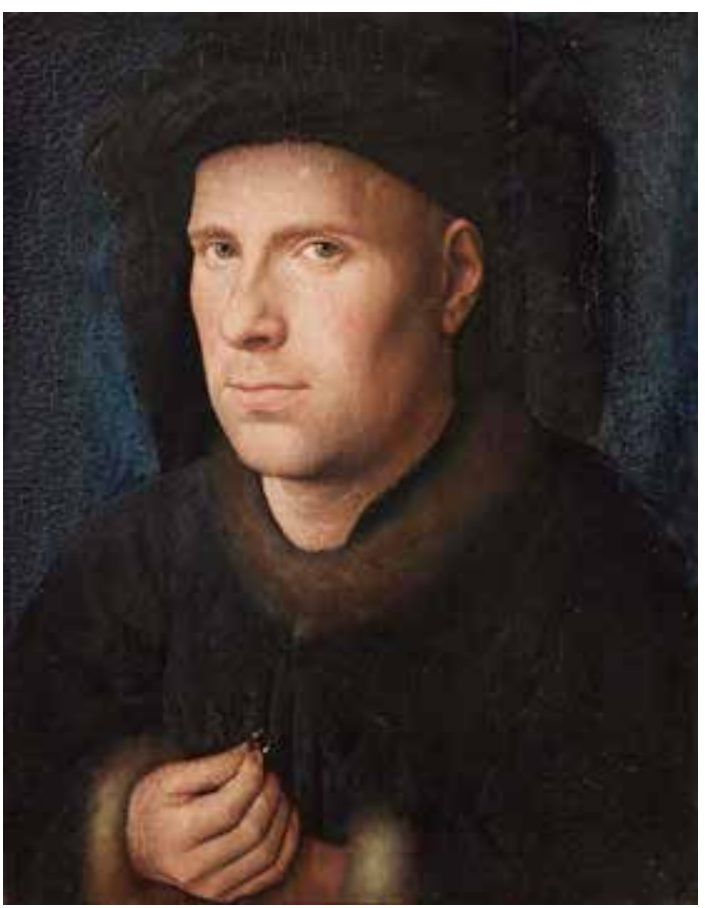

Óleo sobre tabla, 24,5 x 19 cm, Kunsthistorisches Museum, Viena. 
Todorov (2006) sitúa esta revolución del retrato en el Condado de Flandes del siglo Xv. A partir de este momento la pintura flamenca se convierte en un "elogio del individuo" porque, por primera vez, se centra sistemáticamente en la descripción del hombre de a pie. Durante los dos siglos posteriores esta práctica irá dando paso a la "pintura de género", un "elogio de lo cotidiano" que descubre la trascendencia de lo vulgar e insignificante. Y aunque la "pintura de género" y el "retrato" no son lo mismo, pues "los diferencia la intención [filosófica] que los anima" (Todorov, 2013, p. 19), en el elogio de lo cotidiano hay lugar para el elogio al individuo. Así pues, en el siglo XVII, la pintura holandesa se consolida definitivamente como una "pintura de género" centrada en la singularidad de la materia y en la representación de personas anónimas.

Cuando Ortega y Gasset (1965) habla sobre Velázquez afirma que el retrato, en sus manos, se convierte en el "principio de la pintura". Un principio que si bien posee una connotación temporal que consiste en "dar eternidad [...] al instante" (1965, p. 487), también "aspira a individualizar" lo representado, sea cual sea su naturaleza: "La pintura es retrato cuando se propone transcribir la individualidad del objeto. [...] Hace de cada cosa una cosa única" (1965, p. 475). Esto supone un giro revolucionario en el discurso artístico de aquel momento, heredero de la teoría italiana del Renacimiento, que buscaba la representación ideal de la Belleza, es decir, la "corporeidad idealizada" (Ortega y Gasset, 2006, p. 770). Al idealismo del arte italiano se enfrenta el realismo del arte flamenco que busca descubrir la singularidad de cada cosa en sí misma. Mientras que el artista italiano accede a la verdad mediante la belleza en conformidad de la representación con un ideal, el artista flamenco encuentra la belleza en la verdad de lo real. La "verdad humana" se opone al "idealismo poético" (Todorov, 2013, p. 36) porque la idea no se construye, sino que se descubre entre las formas del objeto tal y como se presenta ante la mirada de quien sabe observarlo. Su misma existencia lo hace merecedor del interés humano, y por tanto, digno de ser representado: "La pintura es intrínsecamente elogio de lo que se pinta" (Todorov, 2013, p. 49). En otras palabras, ya no hacen falta motivos más allá de la misma presencia visible de lo material para 
representar y ser representado, y como el artista goza de libertad para elegir la escena que va a representar sin necesidad de comprometerse con la tradición, su modelo puede ser un ciudadano anónimo que no reúna los requisitos de aquellos personajes de los bustos que tanto detestaba Plinio. En esto subyace una actitud ética del artista que reconoce el valor de la vida secular y de lo insignificante, y es en este sentido que "los pintores se convierten ahora en legisladores de la virtud" (Todorov, 2013, p. 74). Al ejercer su poder sobre lo visible, "los flamencos se dan cuenta de que una cierta generalización, ahí donde se esfuma la minucia del detalle, facilita también las posibilidades de personalización del modelo" (Francastel, 1978, p. 96). El artista sintetiza lo que ve y lo que sabe en una "absolutización" de los rostros que atenúa los rasgos individuales, tal como lo hace Van Eyck en los retratos pintados entre 1432 y 1436 (Todorov, 2006, pp. 161-163).

Ahora bien, a medida que desaparecen las particularidades del rostro, aparece con mayor intensidad el trazo del artista. En efecto, es la lucha "entre las formas 'artísticas' y las formas 'naturales' de los objetos" que se da en toda obra pictórica. Si Velázquez es realista e irrealista a la vez es porque transforma la realidad en apariencia al hacer de las cosas que nos rodean "presencias impalpables, incorpóreas" (Ortega y Gasset, 1965, pp. 476-477). Así es como la confusión onírica entre lo real y lo ideal tiene lugar en el retrato que combina lo descriptivo con lo expresivo. Ya Lessing advertía en su Laocoonte (1766) que "las artes plásticas" estarían limitadas a la banal copia del referente si no es gracias a la labor poética del artista, capaz de dominar el tiempo mediante la expresión con el objetivo de provocar una profunda huella en la imaginación del espectador. Su concepto de poesía -que incluye también "a las demás artes cuya imitación es progresiva” (Lessing, 1960, p. 4)- sienta las bases teóricas de un arte romántico que comienza a superar el naturalismo clásico para convertirse en vanguardia. Si "el sueño de la razón produce monstruos" (Caprichos, n.․ 43, 1799) es porque los fantasmas de Goya no son otra cosa que sus propias pinturas. Las máscaras que aparecen entre las sombras de los cuadros del Goya son "puro fantasma lumínico" que enturbia la percepción para iluminar la contemplación; "apariciones" que "nunca llegan a 
instalarse plenamente en la realidad y hacerse del todo patentes, sino que están siempre emergiendo del no ser al ser, de la ausencia a la presencia" (Ortega y Gasset, 2006, p. 772). La balanza de la representación comienza a inclinarse hacia el lado del artista, cuya presencia en el cuadro se acentúa con cada pincelada sin perder su eficacia simbólica. Es más, en los rostros de las pinturas de Goya parece conjurarse la Antigüedad y la Modernidad en el instante que trae al presente las máscaras mortuorias del pasado. Rostros de muertos desprendidos de sus movimientos naturales, algo difusos y desencajados por la pincelada que deja un rastro de inercia visible en el lienzo (imagen 9).

\section{Imagen 9}

Francisco de Goya, El tío Paquete (1819-1820)

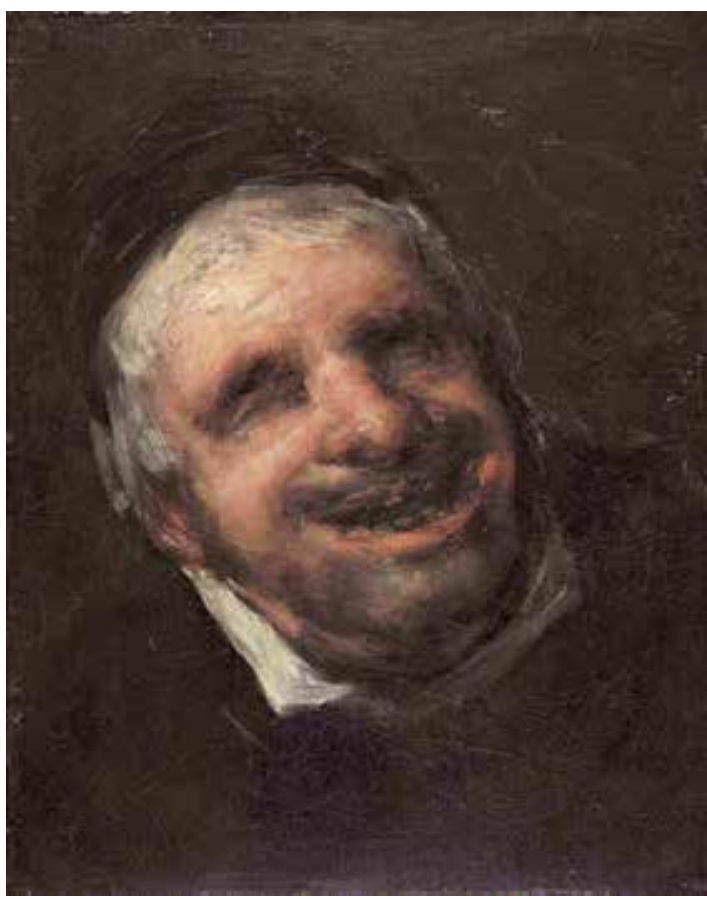

Óleo sobre lienzo, 39 x 31 cm, Museo Nacional Thyssen-Bornemisza, Madrid. 
Para autores como Francastel y Todorov, la obra de Goya es el último elogio al individuo antes de que este vuelva a desaparecer entre las sombras de la "sociedad facial" (Belting, 2017, p. 91). Otros, como Berger (2006, pp. 25-26), van más allá al señalar que el retrato pictórico comienza su declive tras las Monomanies (1821-1824) de Théodore Géricault, coincidiendo "más o menos con la aparición de la fotografía" (2006, p. 19). No obstante, si lo que cuenta es la intención del artista para determinar la función del retrato, no hay motivos para pensar que esto haya cambiado de manera significativa en los tiempos de la sociedad de masas, pues la ingente profusión de rostros no altera en absoluto su condición natural. Así pues, esta saturación no implica necesariamente la muerte del retrato, a no ser que demos por hecho que cuanto más se reproduzca y se consuma el rostro, menor será su valor. Pero entonces se trataría de un valor fetichista, y dicho sea de paso, análogo al de la propia fotografía, pues remite a lo económico más que a lo moral debido a su condición reproducible. En cualquier caso, el retrato ha conocido sus límites sin poner en juego la relación de semejanza con el referente que los flamencos mantenían en delicado equilibrio entre lo real y lo ideal hasta la llegada del impresionismo. El hombre pierde su lugar privilegiado en la representación a medida que fija su mirada en el valor de lo intrascendente y descubre la cosa en su singularidad. Así, paradójicamente, aquello que permitió al individuo salir del anonimato, hogaño lo ha devuelto a una trivialidad identificativa bajo la sombra del exceso ocasionada por la capacidad de reproducción técnica de la fotografía. Con todo, un rostro vacío sigue siendo un rostro, y a pesar de que se pretenda "despersonalizar" y "desimbolizar" al individuo aboliendo "el significado y, por tanto, el signo" de su imagen, "el significante subsiste". Al menos eso nos quiso decir el pop art exhibiendo la "facticidad" de las cosas: los rostros, como los objetos, "significan que no significan nada" (Barthes, 1986, pp. 206-208).

La pincelada que antes difuminaba y luego rasgaba, durante las primeras vanguardias rompe la figura del hombre en mil pedazos para mezclarla con el mundo. Este proceso de objetivación depende de la subjetividad del artista que convierte a las figuras humanas en “soportes fenomenológicos” (Francastel, 1978, p. 223). Aquí comienza 
"la disolución del género" (1978, pp. 212 y ss.), precisamente cuando el arte pretende destruir las convenciones institucionales saliéndose de su discurso. De todas formas, esta conclusión, compartida también por Todorov (2006), solo es válida desde el ideal mimético imperante en Occidente que rechaza como retrato toda forma de representación no descriptiva del individuo. De hecho, si entendemos el retrato como lo hace Borgatti -"the indexing of a particular personality through material objects" (2008, p. 303)-, el motivo para la exclusión de estas representaciones en el género del retrato proviene de un sesgo etnocéntrico (p. 303). Las vanguardias artísticas, conscientes de este error, se alejan de la semejanza, tal y como lo habían hecho la mayoría de las culturas africanas, para reconocer el hombre convertido en una mancha de pintura (imagen 10).

\section{Imagen 10}

Paul Cézanne, Hombre sentado (1905-1906)

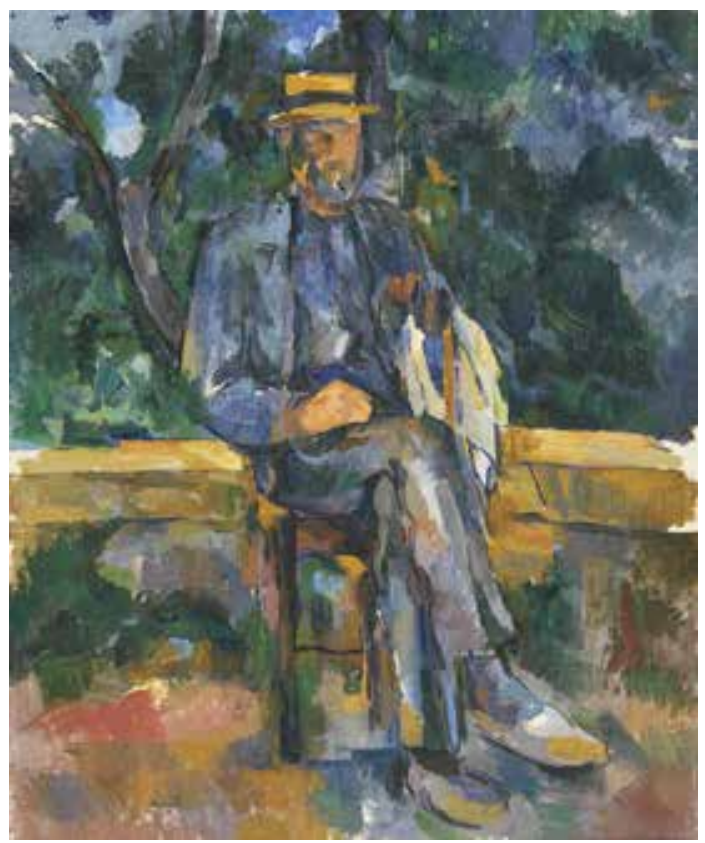

Óleo sobre lienzo, 64,8 x 54,6 cm, Museo Nacional Thyssen-Bornemisza, Madrid. 


\section{Conclusiones}

Podríamos hablar de varios orígenes del arte según el enfoque hermenéutico, puesto que las convenciones que dan forma al retrato dependen de la perspectiva con la que cada cultura afronta la muerte y el problema del arte. Eso sí, todos parecen coincidir en la voluntad de representar al hombre mediante una relación de semejanza que lo sustituya durante su eterna ausencia existencial. Los descendientes de Plinio han tratado de definir y materializar una idea sobre el origen del arte esquiva durante siglos, hasta que la efigie toma un nuevo cariz gracias al giro copernicano que introduce la visión antropocéntrica del pensamiento humanista durante la Modernidad. Ahora son los descendientes de Vasari los que se preguntan en los mismos términos sobre el retrato, algo que, si bien ya estaba en el mito de Plinio, todavía no tenía nombre ni forma. El hombre del Renacimiento tiene derecho a ser representado si en su libertad para hacerse a sí mismo se ha acercado a Dios. El retrato se convierte así en una "celebración social del rostro" (Le Breton, 2013) ante el aspecto intrascendente de la existencia que ya había sido anticipado en tiempos más antiguos. Sabemos que en Egipto se plantearon alternativas a la idealización destinada a los espectadores divinos que esperaban al difunto en el más allá, gracias, en gran parte, a la utilización de nuevas técnicas artísticas que se abrían paso a lo largo de la tradición. De este modo la representación de la realeza egipcia pasó del esquematismo a la individualización mediante la progresiva apropiación de los rasgos identificativos del rostro. Se trata, por tanto, de un cambio en la funcionalidad de la imagen, que con la semejanza ya no buscaba la mirada sacra, sino la mirada humana capaz de reconocer y perpetuar el recuerdo del individuo. De ahí que para la nobleza de la Roma imperial aspirar a la perfecta semejanza en la representación de sus difuntos era el modo de concederles la dignidad que merecían.

Después de un período de oscuridad para el retrato en Occidente entre los siglos IV y IX d. C., en los que solo el papado y la realeza eran dignos del privilegio de ser representados, se vuelve a abrir la mano con la aparición del donante en la escena pictórica sagrada, que con osadía llega a compartir un mismo nivel representacional con aquellas deidades a las que pide protección. Poco a poco, en los siglos 
previos al Renacimiento, el hombre vuelve a mostrar su deseo de ser reconocido como un sujeto desligado de cualquier otra personalidad, ya sea divina o humana, por lo que busca su representación de manera aislada a través de un soporte material que delimite únicamente su busto. Así surge el retrato "libre", "independiente" o "autónomo", cuyas convenciones, afianzadas durante el Renacimiento y refinadas en el Barroco, llegarán a nuestros días para perderse en la saturación de la imagen del rostro que nuestra sociedad masificada consume de manera compulsiva. En cualquier caso, la representación del hombre parece obedecer a una pulsión de permanencia y anclaje material al mundo, ante el miedo a la completa desaparición tras la muerte.

Esta rebelión contra el olvido, tan individualista y a la vez común en todos los hombres, está siempre a la espera de encontrar un medio donde acomodarse. De este modo ha sobrevivido a los diferentes soportes que han ido desapareciendo con el paso del tiempo. Podemos referirnos al retrato, por tanto, como un método cognitivo que no pertenece a un medio específico, y cuyas convenciones se consolidan con el pensamiento humanista. Así pues, el retrato es a la vez una exploración estética del mundo y la huella medial, plástica y simbólica de la existencia, ya que no solo hace presente una imagen de lo ausente, sino que también es un modo de conocimiento antropológico que realiza una "investigación" sobre el modelo. Además de un "signe de reconnaissance -dice Édouard Pommier-, le portrait sera aussi un moyen de connaissance" (1998, p. 24). De ahí que Ricoeur se refiera al modo en que Rembrandt se autorretrataba casi al final de su vida como un "examen de pintura" en el mismo sentido que un "examen de conciencia" (1997, p. 24). Si "el cuadro existe solo como un conjunto de signos donde quedan perpetuadas intenciones" (Ortega y Gasset, 1965, p. 491), la intención del retrato es la descripción del sujeto que "llevada al extremo se transforma en elogio" (Todorov, 2006, p. 195). La necesidad de superar los límites de la representación en busca de la "verdad" velada entre las facciones del rostro provoca la mirada frontal del modelo que se ha convertido en la mirada de la Modernidad, a pesar de su precoz aparición en los albores de nuestra era cristiana y su posterior destierro durante quince 
siglos. Así nos dice el hombre lo que sabe de sí mismo, que, al fin y al cabo, es también lo que sabe de los demás, pues siempre hay algo de universal en la individualidad del retrato. Puede que sea la calavera, como sugiere Bailly, lo que despoja al hombre toda individualidad para convertirse en ser humano (2001, p. 151), y quizá por eso, en ocasiones, nos sentimos atraídos por la imagen del otro como si fuéramos nosotros mismos, pues estamos ante una "antropología pintada" que, siguiendo el sentido abierto por Belting (2009, p. 157), podríamos pensar como una imagen que por su naturaleza demuestra el pensamiento del hombre sobre sí mismo y sobre la humanidad. Al fin y al cabo, el retrato no es solo una "máscara de la historia", sino también la historia del hombre que está por descubrir $\mathbb{C}$

\section{Referencias}

Anónimo (1997). Retórica a Herenio (Intr., trad. y notas de S. Nuñez). Gredos.

Argullol, R. (2009). Carta sobre el retrato. Hernán Cortés Moreno [archivo de blog]. https://bit.ly/3j9V4rR

Bailly, J-C. (2001). La llamada muda: Ensayo sobre los retratos de El Fayum (A. Ruiz de Samaniego, Trad.). Akal.

Barthes, R. (1986 [1982]). Lo obvio y lo obtuso: Imágenes, gestos, voces (C. Fernández Medrano, Trad.). Paidós.

Bataille, G. (2003 [1955]). Lascaux o el nacimiento del arte (A. Gasquet, Trad.). Alción.

Belting, H. (2007 [2002]). Antropología de la imagen (G. M. Vélez Espinosa, Trad.). Katz.

Belting, H. (2009 [1990]). Imagen y culto: Una historia de la imagen anterior a la edad del arte (C. Díez Pampliega y J. Espino Nuño, Trads.). Akal.

Belting, H. (2017). Face and Mask: A Double History (T. S. Hansen \& A. J. Hansen, Trads.). Princeton University Press.

Berger, J. (1998, diciembre 20). El enigma de El Fayum. El País. https:// elpais.com/diario/1998/12/20/cultura/914108405_850215.html 
Berger, J. (2006 [1972]). Sobre las propiedades del retrato fotográfico (P. Vázquez, Trad.). Gustavo Gili.

Blanchot, M. (1976 [1971]). La risa de los dioses (J. A. Doval Liz, Trad.). Taurus.

Borgatti, J. M. (1990). Portraiture in Africa. African Arts, 23(3), 34-39+101. http://www2.clarku.edu/ jborgatt/smfa/borgatti_portraitureAA.pdf

Borgatti, J. M. (2008). Constructed Identities: Portraiture in World Art. En K. Zijlmans \& W. van Damme (Eds.), World Art Studies: Exploring Concepts and Approaches (pp. 303-324). Valiz.

Covarrubias Orozco, S. (1611). Tesoro de la lengua castellana o española. Luis Sánchez. Fondo Antiguo de la Universidad de Sevilla. https://archive. org/details/A253315/page/n1261

Da Vinci, L. (1995 [1888]). Cuadernos de notas (J. L. Velaz, Trad.). PlanetaDe Agostini.

Della Mirandola, P. (1984 [1486]). De la dignidad del hombre (L. Martínez Gómez, Trad.). Editora Nacional.

Debray, R. (1994). Vida y muerte de la imagen: Historia de la mirada en Occidente (R. Hervás, Trad.). Paidós.

Didi-Huberman, G. (2011 [2000]). Ante el tiempo: Historia del arte y anacronismo de las imágenes (A. Oviedo, Trad.). Adriana Hidalgo.

Francastel, G. y Francastel, P. (1978 [1969]). El retrato (E. Alperín, Trad.). Cátedra.

González García, J. L. (2008). Los límites del retrato. En M. Falomir Faus (Ed.), El retrato del Renacimiento (pp. 99-119). Museo Nacional del Prado.

Hegel, G. W. F. (1989). Lecciones de Estética, I (R. Gabás, Trad.). Península. Heródoto [Hdt.]. (1992). Historia [Hist.], II (Euterpe) (Intr. F. Rodríguez Adrados; trad. y notas de C. Schrader). Gredos.

Le Breton, D. (2013). Rostros: Ensayo de antropología (E. Consigli, Trad.). Letra Viva. 
Lessing, G. E. (1960 [1776]). Laocoonte (J. Fernández, Trad.). Universidad Nacional Autónoma de México.

Marcial (2001). Epigramas, II (Intr. J. Fernández Valverde; trad. y notas de A. Ramírez de Verger). Gredos.

Montaigne, M. (2005). Ensayos, I (M-J. Lemarchand, Trad.). Gredos.

Ortega y Gasset, J. (1965). Velázquez. En Obras completas, VIII (1958-1959) (pp. 453-659). Revista de Occidente.

Ortega y Gasset, J. (2006). Papeles sobre Velázquez y Goya. En Obras completas, VI (1941-1955) (pp. 630-774). Taurus.

Petrarca, F. (1516). De los remedios contra prospera y adversa fortuna (F. de Madrid, Trad.). Juan Varela de Salamanca. Fondo Antiguo de la Universidad de Sevilla. https://archive.org/details/ARes64311/ mode/2up

Pommier, É. (1988). Théories du portrait : De la Renaissance aux Lumières. Gallimard.

Pope-Hennessy, J. (1985). El retrato en el Renacimiento (J. Bollo Muro, Trad.). Akal.

Porfirio (1982). Vida de Plotino [Plot.] (J. Igal Alfaro, Trad.). Gredos.

Platón (1987). Crátilo. En Diálogos, II ((Trad., intr. y notas de J. Calonge Ruiz, E. Acosta Méndez, F. J. Olivieri y J. L. Calvo). Gredos.

Platón (1988). República. En Diálogos, IV (Intr., trad. y notas de C. Eggers Lan). Gredos.

Plinio [Plin.]. (2001 [1987]). Textos de Historia del Arte (M.a E. Torrego Salcedo, Trad.). La balsa de la Medusa.

Plutarco (1986). Banquete de los siete sabios. En Obras morales y de costumbres (Moralia), II (Intr., trads. y notas de C. Morales Otal y J. García López) (pp. 207-279). Gredos.

Plutarco (1995). Isis y Osiris. En Obras morales y de costumbres (Moralia), VI (pp. 61-207) (Intr., trads. y notas de F. Pordomingo Pardo y J. A. Fernández Delgado). Gredos. 
Ricoeur, P. (1997). Sobre un autorretrato de Rembrandt. Cuaderno gris, (2), 23-24. https://bit.ly/3naOORI

Stoichita, V. (1999). Breve historia de la sombra (A. M. Coderch, Trad.). Siruela.

Todorov, T. (2006 [2000]). Elogio del individuo: Ensayo sobre la pintura flamenca del Renacimiento (N. Sobregués, Trad.). Círculo de Lectores / Galaxia Gutenberg.

Todorov, T. (2013). Elogio de lo cotidiano: Ensayo sobre la pintura holandesa del siglo XvII (N. Sobregués, Trad.). Círculo de Lectores / Galaxia Gutenberg.

Vasari, G. (1568 [1550]). Le vite de' più eccellenti pittori, scultori e architettori. Giunti - Harold B. Lee Library - Brigham Young University [versión digital]. https://archive.org/details/levitedepiue03vasa1568/page/n5/ mode/2up

Winter, I. J. (2009). What/When Is a Portrait? Royal Images of the Ancient Near East. Proceedings of the American Philosophical Society held at Philadelphia for promoting useful knowledge, 153(3), 254-270. https:// www.jstor.org/stable/40541670

Zerner, H. (1993). L'effet de resemblance. En G. Gentili, P. Morel \& C. Cieri Via (Eds.), Il ritratto e la memoria: Materiale (pp. 111-121). Bulzoni. 